Characterization of bacterial communities associated with Brassica napus L. growing on a Zn-contaminated soil and their effects on root growth Peer-reviewed author version

MONTALBAN GINES, Blanca; CROES, Sarah; WEYENS, Nele; Carmen Lobo, Ma; Perez-Sanz, Araceli \& VANGRONSVELD, Jaco (2016) Characterization of bacterial communities associated with Brassica napus L. growing on a Zn-contaminated soil and their effects on root growth. In: INTERNATIONAL JOURNAL OF PHYTOREMEDIATION, 18(10), p. 985-993.

DOI: $10.1080 / 15226514.2016 .1183566$

Handle: http://hdl.handle.net/1942/22055 


\title{
Characterization of bacterial communities associated with Brassica napus L. growing on a Zn contaminated soil and their effects on root growth
}

\author{
Blanca Montalbán PhD, Sarah Croes, Nele Weyens, M Carmen Lobo, A. \\ Pérez-Sanz \& Jaco Vangronsveld PhD
}

To cite this article: Blanca Montalbán PhD, Sarah Croes, Nele Weyens, M Carmen Lobo, A. Pérez-Sanz \& Jaco Vangronsveld PhD (2016): Characterization of bacterial communities associated with Brassica napus L. growing on a Zn contaminated soil and their effects on root growth, International Journal of Phytoremediation, DOI: 10.1080/15226514.2016.1183566

To link to this article: http://dx.doi.org/10.1080/15226514.2016.1183566

View supplementary material $๘$

Accepted author version posted online: 09 May 2016.

Submit your article to this journal $₫$

Џ Article views: 6

Q View related articles ¿

View Crossmark data ¿ 


\title{
ACCEPTED MANUSCRIPT
}

Characterization of bacterial communities associated with Brassica napus L. growing on a Zn contaminated soil and their effects on root growth

Blanca Montalbán $\mathrm{PhD}^{1, *}$, Sarah Croes ${ }^{1, * *}$, Nele Weyens ${ }^{1, \$}$, M Carmen Lobo $^{2}$, A. Pérez-Sanz ${ }^{3}$, Jaco Vangronsveld Ph.D Professor ${ }^{4}$

${ }^{1}$ Hasselt University, Centre for Environmental Sciencies, Environmental Biology, Diepenbeek, Belgium

${ }^{2}$ IMIDRA, Finca “El Encin” A-2, Km 38,2, Alcalá de Henares, Spain, carmen.lobo@madrid.org ${ }^{3}$ IMIDRA, Agroenviroment Research, Finca “El Encín”, A-II km 38,200, Alcalá de Henares, 28800 Spain, araceli.perez@madrid.org

${ }^{4}$ Hasselt University, Environmental Biology, Agoralaan, building D, Diepenbeek, B-3590

Belgium, jaco.vangronsveld@uhasselt.be

*Corresponding Author E-mail: blanca.montalban@madrid.org

*** Corresponding Author E-mail: sarah.croes@uhasselt.be

${ }^{\$}$ Corresponding Author E-mail: nele.weyens@uhasselt.be

Detailed phenotypic characterization of all the bacterial strains isolated can be found as supporting information.

\section{The authors have no conflict of interest to declare}

\begin{abstract}
The interaction between plant growth-promoting bacteria (PGPB) and plants can enhance biomass production and metal tolerance of the host plants. This work aimed at isolating and characterizing the cultivable bacterial community associated with Brassica napus growing on a
\end{abstract}




\section{ACCEPTED MANUSCRIPT}

Zn contaminated site, for selecting cultivable PGPB that might enhance biomass production and metal tolerance of energy crops. The effects of some of these bacterial strains on root growth of B. napus exposed to increasing $\mathrm{Zn}$ and $\mathrm{Cd}$ concentrations were assessed. A total of 426 morphologically different bacterial strains were isolated from the soil, the rhizosphere, the roots and stems of B. napus. The diversity of the isolated bacterial populations was similar in rhizosphere and roots, but lower in soil and stem compartments. Burkoholderia, Alcaligenes,Agrococcus, Polaromonas, Stenotrophomonas, Serratia, Microbacterium and Caulobacter were found as root endophytes exclusively. The inoculation of seeds with Pseudomonas sp. strains 228 and 256, and Serratia sp. strain 246 facilitated the root development of B. napus at $1000 \mu \mathrm{M}$ Zn. Arthrobacter sp. strain 222, Serratia sp. strain 246, and Pseudomonas sp. 228 and 262 increased the root length at $300 \mu \mathrm{M} \mathrm{Cd}$.

\section{Key words}

Plant-associated bacteria, endophytes, inoculation, plant growth-promoting bacteria, phytoremediation 


\section{ACCEPTED MANUSCRIPT}

\section{Introduction}

The number of areas polluted due to excess of metals and metalloids was growing due to the increase of anthropogenic activities such as mining, metallurgical industries, electroplating, manufacturing of plastics, paint pigments, alloy preparation and batteries, energy and fuel production and application of fertilizers and pesticides (Broadley et al., 2007; Kirkham 2006; Panagos et al., 2013). Several metals such as Cd can be accumulated in the food chain through uptake at the primary producer level and subsequently through transfer and bioaccumulation at higher trophic levels (Nagajyot et al., 2010). Phytoextraction is a low cost technology that uses green plants to extract metals and metalloids from the soil and accumulate them in the harvestable plant parts. However, the low biomass production of most hyperaccumulator species, along with their low economic value (Vamerali et al., 2010), led to a search for higher-biomass accumulator crops. Making use of these crops can provide renewable biomass that can be used for bioenergy production, ecomaterials or biocatalysis, and at the same time to remediate metalcontaminated soils that can no longer be used for food and feed production (Vangronsveld et al., 2009; Witters et al., 2012; Kidd et al., 2015).

Metal availability, uptake and phytotoxicity are some of the main limiting factors of phytoextraction in metal-contaminated soils (Weyens et al., 2009b). In case of high metal availability, energy crops that are effective in removing metals from soils can show a reduced growth due to phytotoxicity, thereby decreasing both the amount of marketable biomass and the remediation efficiency. The interaction between plant growth-promoting bacteria (PGPB) and plants can frequently enhance biomass production and metal tolerance of the plants (Germida et al., 1998; Genrich et al., 2000; Zhang et al., 2012), diminishing symptoms of phytotoxicity. 


\section{ACCEPTED MANUSCRIPT}

Some metal tolerant PGPB bacteria from soil, rhizosphere or endophytes have the capacity to promote plant growth through mechanisms such as nitrogen fixation, production of siderophores and phytohormones (such as IAA, indole-3-acetic acid), solubilization of minerals like phosphorous, and production of 1-aminocyclopropane-1-carboxylate (ACC) deaminase (Glick et al., 2003; Rajkumar et al., 2009; Weyens et al., 2009b; Sessitsch et al., 2013). The latter enzyme has received increasing attention because of its role in lowering ethylene levels in a stressed plant. The presence of toxic amounts of metals, and other types of stress like high salt concentrations or phytopathogens induce elevated ethylene levels (mainly) causing inhibition of root growth and development (Glick, 2010; Schellingen et al., 2014). Further, some bacteria can solubilize unavailable forms of potentially toxic elements in soils by excreting organic acids and siderophores (Ma et al., 2009). On the other hand, some plant-associated bacteria can reduce the metal uptake by binding metals to anionic functional groups or to extracellular polymeric substances (Rouch et al., 1995; Ma et al., 2011; Rajkumar et al., 2012). Extending our knowledge about these bacterial characteristics and the action mechanisms of PGPB is important for the development of more effective phytotechnologies for metal-contaminated sites (Zhang et al., 2011; Sessitsch et al., 2013).

Brassica napus L. (rapeseed) is a well-known high-biomass crop commonly used for bioenergy production. Many studies mentioned the tolerance of this crop to toxic amounts of metals, such as $\mathrm{Cd}$ and $\mathrm{Zn}$, as well as its capacity to accumulate them in their tissues (Marchiol et al., 2004; Grispen et al., 2006; Hernández-Allica et al., 2008). Based on its characteristics, B. napus can be a suitable candidate for phytoextraction purposes and to produce valorizable biomass on $\mathrm{Cd} / \mathrm{Zn}$ contaminated land (Marchiol et al., 2004; Croes et al., 2013). 


\section{ACCEPTED MANUSCRIPT}

This work aimed at isolating and characterizing the cultivable bacterial communities associated with $B$. napus growing on a Zn-contaminated site, for selecting cultivable PGP bacterial strains that might enhance biomass production and tolerance of B. napus on $\mathrm{Zn}$-contaminated land. Long-term polluted soils are sources of metal-tolerant microorganisms and interesting interactions with the plants that are growing in these soils, such as PGP characteristics (BecerraCastro et al., 2012). A further objective is to evaluate the effects of PGP bacterial strains on root growth of B. napus in the presence of increasing concentrations of $\mathrm{Zn}$ or $\mathrm{Cd}$, using vertical agar plates (VAPs). Here, VAPs will be used to perform preliminary inoculation experiments for selecting potential cultivable PGP bacteria having positive effects on root structure (Zhang et al., 1998; Remans et al., 2006), while avoiding competition with other microorganisms (ReynosoCuevas et al., 2008).

\section{Experimental Procedures}

\subsection{Sampling}

The experimental field $\left(50^{\circ} 59^{\prime} 23^{\prime \prime} \mathrm{N}, 5^{\circ} 14^{\prime} 21^{\prime \prime} \mathrm{E}\right)$ was situated in Lummen (Belgium) near a zinc recycling plant that started its activities mid-1975. In the early days, only crude zinc ashes of hot-dip galvanizers were processed. From1982 they started processing of zinc scrap to zinc metal. The contamination on the site that is causing phytotoxicity is limited to $\mathrm{Zn}$, although total $\mathrm{Pb}$ concentrations are also clearly higher than background values (Table 1). Cadmium concentrations are within the range of background values in Flanders.

In September 2011, B. napus cultivar Remy seeds were sown (50-80 plants per $\mathrm{m}^{2}$ ) on this site. Two weeks before sowing, $3 \mathrm{~cm}$ of compost (based on horse and chicken manure), was applied 


\section{ACCEPTED MANUSCRIPT}

and worked in the soil using rototilling. Soils and plants were sampled in April 2012. Plants were sampled in the flowering stage.

\subsection{Metal concentrations in soils and plants}

Metal concentrations were determined in three replicates of soil and plant samples. The extractable fractions of metals in soil were estimated using $0.1 \mathrm{M} \mathrm{Ca}\left(\mathrm{NO}_{3}\right)_{2}$ (Mench et al., 1994). (Pseudo)-total concentrations of metals in soil were determined by aqua regia digestion (Van Ranst et al., 1999). Plants were washed with distilled water, separated into leaves, stems and roots, and then dried for $48 \mathrm{~h}$ at $65^{\circ} \mathrm{C}$. Subsequently, the dried tissues were ground and digested according to Weyens et al. (2010). Metal concentrations in the extracts were determined using inductively coupled plasma optical emission spectrometry (ICPOES). The quality of the digestion and analytical methods was tested including blanks and certified reference material (NIST Standard Reference Material 1570a, Trace elements in Spinach, U.S. Department of Commerce, National Institute of Standards and Technology) with every set of samples.

\subsection{Isolation of cultivable bacterial strains}

Cultivable bacteria were isolated from bulk soil, rhizosphere soil, roots and stems of $B$. napus following the sampling design of Croes et al. (2015). The isolation procedure was carried out according to Weyens et al. (2009a), but in this work, the sodium hypochlorite solution (1\%) and time $(1 \mathrm{~min})$ during root surface sterilization were modified. Colony-forming units (cfu) were counted and calculated per gram soil or fresh plant weight. All morphologically different 


\section{ACCEPTED MANUSCRIPT}

strains were purified using five replicates and then stored at $-70^{\circ} \mathrm{C}$ in a solution with $15 \%(\mathrm{w}: \mathrm{v})$ glycerol and $0.85 \%(w: v) \mathrm{NaCl}$.

\subsection{Phenotypic characterization}

Purified bacterial strains were grown in 869 medium (Mergeay et al., 1985), then washed twice with sterile $10 \mathrm{mM} \mathrm{MgSO} 4$ (Croes et al., 2013) and tested for their $\mathrm{Zn}$ and Cd tolerance and potential plant growth-promoting (PGP) characteristics (phosphate solubilization, nitrogen fixation, ACC-deaminase activity and production of siderophores, organic acids, IAA and acetoin). Strains not able to grow in the test medium were considered as not detectable (nd). Media without bacteria were used as controls. The PGP characteristics were screened as described previously by Croes et al. (2013).

For testing the bacterial tolerance to either $\mathrm{Zn}$ or $\mathrm{Cd}$ all strains were grown on selective 284 medium with a C-mix (per liter medium, $0.52 \mathrm{~g}$ glucose, $0.35 \mathrm{~g}$ lactate, $0.66 \mathrm{~g}$ gluconate, $0.54 \mathrm{~g}$ fructose, and $0.81 \mathrm{~g}$ succinate) as described by Weyens et al. (2009a) and 1mM of Zn (added as $\mathrm{ZnSO}_{4}$ ) or $0.8 \mathrm{mM}$ of $\mathrm{Cd}$ (added as $\mathrm{CdSO}_{4}$ ). Tolerance was assessed visually.

\subsection{Genotypic characterization}

Total genomic DNA was extracted from all purified morphologically different bacterial strains by the DNeasy® Blood and tissue kit (Qiagen, Valencia, CA, USA). Polymerase chain reaction (PCR) amplification of the 16S rRNA genes of the extracted DNA was carried out using the universal primers, 16S-prokaryotic-R (5'-ACGGGCGGTGTGTRC-3') and 16S-prokaryotic-F (5'-AGAGTTTGATCCTGGCTCAG-3') according to Weyens et al. (2009a). 


\section{ACCEPTED MANUSCRIPT}

PCR products were directly used for ARDRA and sequencing. For amplified 16S rDNA restriction analysis (ARDRA), $10 \mu \mathrm{L}$ of the PCR products were digested with the restriction endonuclease HpyCH4 IV (New England Biolabs, Beverly, MA, USA) and separated by electrophoresis (Weyens et al. 2009a). Bacterial strains with the same ARDRA patterns were grouped within each compartment (stem, root, rhizosphere, and soil). The PCR products of one representative strain per compartment were purified according QIAlquick 96 PCR Purification Kit (Qiagen, Valencia, CA, USA). Purified 16S rRNA genes were sent for sequencing by Macrogen (Korea) with an Automatic Sequencer 3730XL. Sequenced strains were identified by means of Sequence Match at the Ribosomal Database Project II. All strains had a sequence match score higher than 0.900 .

Partial 16S-rDNA gene sequences were submitted to GenBank (National Center for Biotechnology Information, NCBI) with the accession numbers KT461822- KT461878.

\subsection{Effects of inoculation on root growth}

Certified seeds of B. napus L. cv. Nodari (Syngenta Seeds) were surface sterilized by immersing them in $0.1 \%$ sodium hypochlorite for 1 minute, then washed three times with Millipore water. Some surface-sterilized seeds were grown during 3 days at $30^{\circ} \mathrm{C}$ on 869 rich solid medium (Mergeay et al., 1985) in order to verify the surface sterilization process. Seeds were considered surface sterilized when no bacterial growth was observed. Bacterial strains were grown on 869 liquid medium for $12 \mathrm{~h}$ at $30^{\circ} \mathrm{C}$, centrifuged at $1811 \mathrm{~g}$ during $10 \mathrm{~min}$, washed two times and resuspended in $10 \mathrm{mM} \mathrm{MgSO}_{4}$. Surface-sterilized seeds were immersed in a bacterial suspension $\left(10^{8} \mathrm{cfu} \mathrm{mL}^{-1}\right)$ for $1 \mathrm{~h}$ at room temperature. Subsequently, the seeds were placed in 


\section{ACCEPTED MANUSCRIPT}

Petri dishes with $1 / 10$ diluted 869 solid medium for 1 day at $25^{\circ} \mathrm{C}$ in darkness. Finally, the inoculated seeds were put into square vertical plates (Zhang et al., 1998) with MS medium spiked separately with 300 and $1000 \mu \mathrm{M}$ of $\mathrm{Zn}\left(\mathrm{ZnSO}_{4} \cdot 7 \mathrm{H}_{2} \mathrm{O}\right)$ and 50 and $300 \mu \mathrm{M}$ of $\mathrm{Cd}$ $\left(\mathrm{CdSO}_{4} .8 \mathrm{H}_{2} \mathrm{O}\right)$. The metal doses used in this experiment were chosen according to the tolerance shown by $B$. napus in the presence of increasing doses of $\mathrm{Cd}$ and $\mathrm{Zn}$ under in vitro conditions (Montalbán et al., 2014). Non-inoculated surface-sterilized seeds were immersed in 10mM $\mathrm{MgSO}_{4}$ and were used as controls in plates with MS medium non-spiked (Control) and spiked (Non-inoculated). All plates were set up vertically in a growth chamber at $23^{\circ} \mathrm{C} / 12{ }^{\circ} \mathrm{C}$ and $12 \mathrm{~h}$ of photoperiod. After 5 days, the root systems in the vertical plates were scanned, and root length was determined after analysis of scanned images using the Optimas Image Analysis Software 6.0 (MediaCybernetics) according to Remans et al. (2006).

\subsection{Statistical analysis}

Statistical analysis of the VAPs results was done using the IBM SPSS Statistics 19.0 software. One-way analysis of variance (ANOVA) and Tukey's test were applied in this case. Differences at $\mathrm{p} \leq 0.05$ level were considered significant. Genotypic information was subjected to correspondence analysis (CA), a principal component analysis related ordination technique based on chi-square distances, illustrating correlations between compartments to evaluate the isolation procedure (Croes et al., 2015). CA was done using the statistical software package $\mathrm{R}$ (http://cran.at.r-project.org).

\section{Results and discussion}

\subsection{Soil}




\section{ACCEPTED MANUSCRIPT}

The total and $\mathrm{Ca}\left(\mathrm{NO}_{3}\right)_{2}$-extractable $\mathrm{Zn}$ and $\mathrm{Cd}$ concentrations in the soil are shown in Table 1. The soil presented sandy texture, $\mathrm{pH} 5.6$ and $1.9 \%$ organic matter. As compared to background values and clean up values for metals in agricultural soils based on the Flemish legislation on soil remediation (VLAREBO, 2009), only total Zn concentrations were in excess. However the Ca $\left(\mathrm{NO}_{3}\right)_{2}$-extractable $\mathrm{Zn}$ concentration was high in comparison to non-polluted soils (unpublished results) (try to compare with data in the literature notably leading to Zn phytotoxicity or $\mathrm{Cd}$ eontamination of foed; total soil $\mathrm{Zn}$ and $\mathrm{Cd}$ is not the most important; it is the labile poels at such acidic soil $\mathrm{pH})$.

\subsection{Bacteria isolated from B. napus growing on a Zn contaminated site}

A total of 426 morphologically different cultivable bacterial strains were isolated from bulk soil, rhizosphere soil, roots and stems of the B. napus plants. The numbers of different genera were similar in rhizosphere (20) and root (17), but lower in soil (8) and stem (3) compartments (Table 2). The lower diversity of bacteria found in soil with respect to rhizosphere and roots can be explained as a rhizosphere selection by the plant on its surrounding bacterial community (Gomez-Balderas et al., 2014). The number of cultivable strains found in rhizosphere soil was two orders of magnitude higher than in bulk soil and roots. The decline of the bacterial numbers from the rhizosphere to the roots and soil was previously reported by authors investigating $B$. napus associated bacteria (Germida et al., 1998; Croes et al. 2013). This high density of cultivable bacteria in the rhizosphere is due to root exudates that provide high amounts of organic carbon directly to microbial populations, in comparison with the slow decomposition of recalcitrant organic matter in the bulk soil (Soderberg and Bååth, 1998). Microorganisms indeed 


\section{ACCEPTED MANUSCRIPT}

are attracted by carbohydrates, amino acids and organic acids that are present in the rhizosphere as root exudates and mucilage-derived components (Compant et al., 2010).

On the other hand, the number of endophytic bacteria recovered from the roots was three orders of magnitude higher than in stem samples (Table 2). The numbers of endophytes found in roots and stems are in accordance with earlier reports (Lodewyckx et al., 2002). This high density of bacteria in the lower parts of the plant with respect to upper parts was previously reported by Fisher et al. (1992). This supports the idea that at least part of the colonization of the plant interior occurred from the rhizosphere via the root system, through wound sites, root hairs and epidermal junctions (Weyens et al. 2009a; Becerra-Castro et al. 2011), and mainly during the first stages of root development when tissues are still undifferentiated (Hallmann et al., 2001). Besides, some studies have suggested an active penetration of endophytes through enzymatic degradation of plant cells (Lodewyckx et al., 2002; Truyens et al., 2014).

\subsection{Genotypic characterization}

In total, 33 different bacterial genera were identified. The pie diagrams in Figure 1 show the diversity and relative abundance of bacterial genera present in each compartment. Each color and number relates to a different bacterial genus and subdivided colors represent bacterial genera with different accession numbers. Eight different genera of bacteria were identified in bulk soil, with Arthrobacter (45.9\%) and Bacillus (41.7\%) as dominant genera in this compartment. The high abundance of Arthrobacter sp. was not surprising, taking into account that it is considered as one of the most predominant members of cultivable soil microorganisms (Hanbo et al., 2004). Moreover, this genus is in high abundance in Zn-polluted soils (Dell' Amico et al., 2005). Also Bacillus was reported as a dominant genus in $\mathrm{Cu}-\mathrm{Pb}-\mathrm{Zn}$ contaminated soil (Ellis et al., 


\section{ACCEPTED MANUSCRIPT}

2003). Twenty different genera of bacteria were identified in the rhizosphere, of which Variovorax (47.2\%), Arthrobacter (16.9\%), Bacillus (10.5\%), and Staphylococcus (8.8\%) were most dominant. The presence of these genera in the rhizosphere of B. napus was observed previously by other authors (Germida et al. 1998; Croes et al., 2013).

Endophytic bacterial strains identified in roots belonged in particular to the genera Pseudomonas (33.8\%), Burkholderia (30.6\%), Variovorax (21.1\%)

and Pedobacter(7.4\%). In stems, Pedobacter (66.7\%) and Micrococcus (27.9\%) dominated the cultivable bacterial population.

Although Pseudomonas, Bacillus, Enterobacter and Agrobacterium are the most commonly isolated bacterial genera (Becerra-Castro $e t$ al., 2011), in this work, Enterobacter and Agrobacterium were not isolated from any of the investigated compartments. Field studies on metal contaminated soils have shown that high levels of metals can modify the structure of microbial communities and decrease microbial diversity (Kelly et al. 2003, Dell' Amico et al., 2005).

Paenibacillus, Niastella and Brevundimonas were only found in the bulk soil. GomezBalderas et al. (2014) and Croes et al., (2013) also isolated the genus Brevundimonas from a ZnCd contaminated soil, but both studies did not report it in non-contaminated soils, indicating the eventual adaptation of this genus to $\mathrm{Zn}$ and $\mathrm{Cd}$ contaminated sites. On the contrary, Arthrobacter and Variovorax were present in all compartments studied, except in the stem.

Staphylococcus, Shinella, Bosea, Chryseobacterium, Proteobacterium a/b, Patulibacter, Leifsoni a, Dyadobacter and Methylobacter were found only in the rhizosphere. 


\section{ACCEPTED MANUSCRIPT}

However, Agromyces, Pseudomonas, Lysobacter, Sphingopyxis and Mitsuaria were present in the rhizosphere and also as root endophytes. Agromyces was also found to be a stem endophyte. Burkholderia, Alcaligenes, Agrococcus, Polaromonas, Stenotrophomonas, Serratia, Microbacterium and Caulobacter were root endophytes exclusively. Serratia species were also found as root endophytes in the Cd-hyperacumulator Solanum nigrum by Chen et al. (2012). Here, Pedobacter was found as root and stem endophyte, however, Micrococcus was exclusively present in the stem. Micrococcus sp. were also found by Velazquez et al. (2008) in stems of sugarcane and by Germida et al. (1998) in roots of Brassica napus, confirming the ability of this genus to colonize plant tissues.

The genera Cupriavidus, Niastella, Agromyces, Shinella, Bosea, Proteobacterium, Lysobacter, Shingopyxis, Patulibacter, Mitsuaria, Dyadobacter, Methylobacter, Alacaligenes, Agrococcus and Polaromonas were isolated in this study (Figure 1), but were not previously reported for bacterial communities associated with B. napus (Croes et al., 2013; Germida et al., 1998). This can be due to (a) specific soil factors that could affect the rhizosphere populations (Bulgarelli et al., 2012), and also (b) to the different concentrations of the (available) metals in the soil. Moreover, (c) the surface sterilization method employed, (d) the growth medium used for isolation (Lodewyckx et al., 2002) and (e) the different growth stages of the host plants at the moment of sampling could also affect the bacterial populations (de Campos et al., 2013; Croes, 2014).

Croes et al. (2013) reported that the most dominant root cultivable endophytes in B. napus were the genera Pseudomonas, Pedobacter and Variovorax. In this work, these genera were found in similar percentages. Taking into account that the seeds sown in our field originated from the 


\section{ACCEPTED MANUSCRIPT}

same seed stock as the one used by Croes et al. (2013), our results suggest that these endophytes remained present in the stored seeds..

According to the correspondence analysis (Figure 2), the mean cultivable rhizosphere bacterial community was more correlated $(\mathrm{CC}=0.43)$ with the mean soil bacterial community than with the endophytic communities found in the roots and stems $(\mathrm{CC}=0.35$ and -0.08 , respectively). This indicates that rhizosphere, bulk soil and root shared a high percentage of bacterial genera. However, the stem showed a higher number of genera specific for this compartment.. Root and stem bacterial communities showed a low correlation coefficient $(\mathrm{CC}=$ 0.06), indicating the presence of different bacterial genera. Several authors reported significant differences in bacterial communities between below-ground and above-ground plant parts, demonstrating that the organs of the plants have different bacterial communities associated with them (Lindow and Brandl, 2003; Izumi et al., 2008; Weyens et al., 2009a; Croes et al., 2013).

\subsection{Phenotypic characterization}

A high percentage of stem endophytes showed tolerance to $1 \mathrm{mM} \mathrm{Zn}$, but they were not able to grow on 284 medium supplemented with $\mathrm{C}$-mix and $0.8 \mathrm{mM} \mathrm{Cd}$ (Table 3). The $\mathrm{Zn}$ concentrations in leaf, stem and roots of $B$. napus collected in the field were $1013 \pm 207,1301 \pm$ 196 and $941 \pm 138 \mathrm{mg} \mathrm{kg} \mathrm{dry} \mathrm{weight}{ }^{-1}$, respectively. The Cd concentrations were $1.4 \pm 0.5,1.6 \pm$ 0.6 and $1.2 \pm 0.3 \mathrm{mg} \mathrm{kg}$ dry weight ${ }^{-1}$ in leaf, stem and root, respectively. The high stem $\mathrm{Zn}$ concentration might explain why the endophytes were more frequently tolerant to $1 \mathrm{mM} \mathrm{Zn}$. In contrast to the bacterial strains isolated from the stems, $21.7 \%$ of the root endophytes were tolerant to $\mathrm{Cd}$. The percentages of rhizosphere and soil strains that were tolerant to $0.8 \mathrm{mM} \mathrm{Cd}$ 


\section{ACCEPTED MANUSCRIPT}

and $1 \mathrm{mM} \mathrm{Zn}$ were similar for both compartments. Croes et al. (2013) compared the metal tolerance of bacterial strains isolated from a $\mathrm{Zn} / \mathrm{Cd}$-contaminated field and a control field: the highest numbers of bacterial strains tolerant to $1.6 \mathrm{mM} \mathrm{Cd}$ and $2.5 \mathrm{mM} \mathrm{Zn}$ originated from the contaminated field. They suggested that the concentrations of metals present in the soil stimulated the presence of bacteria tolerant to both metals.

Stem endophytes could not solubilize phosphorus or produce siderophores (Table 3). Many of them were able to fix nitrogen and produce organic acids. The highest percentages of bacterial strains able to solubilize phosphorus and produce siderophores, IAA and ACC deaminase were found in the roots. In contrast, the highest percentage of bacterial strains capable of producing acetoin was found in the stems. Our results suggest that the production of organic acids, IAA and ACC deaminase are important bacterial characteristics in soil and roots, however, siderophore production occurs predominantly in root bacteria.

A comparison of phenotypic characteristics of bacterial communities that were isolated in different studies is complicated due to the large variation that exists between different plant species, growth conditions and concentrations of metals in the plant (Chen et al., 2012). However, metal excess in soils can stimulate the production of bacterial siderophores that can decrease metal toxicity by providing iron to the plant (Dell' Amico et al., 2005). Moreover, the production of IAA and ACC deaminase can stimulate root growth in presence of metals and also the root exudation that promotes the bacterial proliferation in the rhizosphere (Glick et al., 2010).Our results support these hypotheses, due to the fact that most of the bacterial strains isolated from the Zn contaminated site show potential PGP characteristics (Table 3).

\subsection{Inoculation of B. napus seeds with PGPB}




\section{ACCEPTED MANUSCRIPT}

Six Cd-Zn-tolerant bacterial strains (Staphylococcus sp. 25, Arthrobacter sp. 222, Pseudomonas sp. 228, Serratia sp. 246, Pseudomonas sp. 256, Pseudomonas sp. 262) isolated from bulk soil, rhizosphere and roots of $B$. napus growing on the $\mathrm{Zn}$ contaminated site) were selected based on their PGP characteristics (Table 4) to be inoculated on B. napus seeds. Root length was the parameter used to evaluate the effects of the bacteria on the growth and tolerance of the seedlings to both metals. The architecture of a root system is determined by the intrinsic developmental program but also, by external biotic and abiotic stimuli (Zhang et al., 1998), such as the presence of toxic concentrations of metals in the growth medium (Remans et al., 2012). Root growth has been often used to evaluate the plant tolerance to metals (Peralta et al., 2001, Azevedo et al., 2005), and it is one of the best markers to evaluate the effects of PGP bacteria on plant growth (Pattern and Glick, 2002).

B. napus did not exhibit significant differences in root length between seedlings grown with low concentrations of $\mathrm{Zn}$ or $\mathrm{Cd}(300 \mu \mathrm{M}$ and $50 \mu \mathrm{M}$, respectively) and controls (Figure 3). However, root length decreased at higher doses of both metals $(1000 \mu \mathrm{M} \mathrm{Zn}$ and $300 \mu \mathrm{M} \mathrm{Cd}) . \mathrm{Cd}$ can be highly phytotoxic, even at low concentrations (Groppa et al. 2008). On the contrary, zinc ( $\mathrm{Zn}$ ) is an essential micronutrient, required by plants to grow, but it becomes toxic at higher levels (Marques et al., 2013). The positive effect of bacterial inoculation of the seeds on root growth was observed only at high doses of both metals. Pseudomonas sp. strain 228 and 256, and Serratia sp. strain 246, significantly increased root length of B. napus when exposed to $1000 \mu \mathrm{M}$ Zn (Figure 3a). Arthrobacter sp. strain 222, Serratia sp. strain 246, Pseudomonas sp. 228 and 262 significantly increased root length of B. napus seedlings at $300 \mu \mathrm{M} \mathrm{Cd}$ in comparison to non-inoculated ones (Figure 3b). 


\section{ACCEPTED MANUSCRIPT}

In general, the inoculated bacterial strains were able to produce siderophores, indole-3-acetic acid (IAA) and exhibited ACC deaminase activity (Table 4). Pseudomonas sp. strain 228 and Serratia sp. strain 246 produced organic acids, and Pseudomonas sp. strain 256 could produce acetoin and fix nitrogen. Moreover, both Pseudomonas strains could solubilize phosphorous. Arthrobacter sp. strain 222 and Pseudomonas sp. strain 262 showed high ACC deaminase activities and moderate production of organic acids. Pseudomonas sp. strain 262 was also able to produce acetoin. Arthrobacter sp. strain 222 was the only strain that did not possess the capacity to produce siderophores or IAA, but was able of fixing nitrogen.

A positive effect due to inoculated bacterial strains on root growth of Cd-exposed B. napus was also observed by Sheng et al. (2006) after inoculation with Pseudomonas sp. and Bacillus sp., both being IAA producers. Many studies have reported positive effects of inoculated bacteria on plant growth (Glick, 2010). IAA (indole-3-acetic acid) and acetoin (3-hydroxy-2butanone) production have been shown to stimulate root formation (Duan et al., 2013), and ACC deaminase activity to protects against the growth inhibiting effects of various stresses such as toxic concentrations of metals (Glick, 2003). The PGP characteristics of the inoculated bacterial strains could play an important role in the root growth of $B$. napus seedlings in the presence of toxic concentrations of $\mathrm{Zn}$ and $\mathrm{Cd}$. Further studies are necessary for investigating the growthpromoting properties of these bacterial strains in field soils where there is competition between indigenous microorganisms and where nutrients are present in more recalcitrant forms.

\section{Conclusions}

The isolation of bacteria associated with B. napus growing on a $\mathrm{Zn}$ contaminated site led to the identification of $\mathrm{Zn}$ - and/or Cd-resistant bacterial strains with potential PGP characteristics. Seed 


\section{ACCEPTED MANUSCRIPT}

inoculation of Pseudomonas sp. 228, Serratia sp. 246 and Pseudomonas sp. 256 improved root

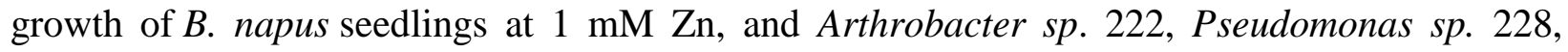
Serratia sp. 246 and Pseudomonas sp. 262 at $300 \mu \mathrm{M}$ Cd. Future work should be performed on soils from the field to evaluate the effects of these bacterial strains on plant growth and metal uptake, in order to select bacterial strains that can be used to improve remediation and biomass production on contaminated soils.

\section{Acknowledgements}

The authors would like to acknowledge INIA to support the grant of B. Montalbán (FPI-INIA 2010), EIADES PROGRAM S2009/AMB-1478, RTA000150-00-00-INIA project and UHasselt Methusalem project 08M03VGRJ. S. Croes and N. Weyens are grateful to the FWO (Fund for Scientific Research Flanders) for respectively a $\mathrm{PhD}$ and post-doc grant. 


\section{ACCEPTED MANUSCRIPT}

\section{References}

Azevedo H, Pinto GGC, Fernandes J, Loureiro S, Santos C. 2005. Cadmium effects on sunflower growth and photosynthesis. Journal of Plant Nutrition 28: 2211-2220.

Becerra-Castro C, Kidd PS, Prieto-Fernández A, Weyens N, Acea MJ, Vangronsveld J. 2011. Endophytic and rhizoplane bacteria associated with Cytisus striatus growing on hexachlorocyclohexane-contaminated soil: isolation and characterization. Plant Soil 340:413433.

Becerra-Castro B, Monterroso C, Prieto-Fernández A, Rodríguez-Lamas L, Loureiro-Viñas M, Acea MJ, Kidd PS. 2012. Pseudometallophytes colonising Pb/Zn mine tailings: A description of the plant-microorganism-rhizosphere soil system and isolation of metal-tolerant bacteria. Journal of Hazardous Materials 217-218: 350-359.

Broadley MR, White PJ, Hammond JP, Zelko I, Lux A. 2007. Zinc in plants. New Phytologist 173: $677-702$.

Bulgarelli D, Rott M, Schlaeppi K, Ver Loren van Themaat E, Ahmadinejad N, Assenza F, Rauf P, Huettel B, Reinhardt R, Schmelzer E, Peplies J, Gloeckner FO, Amann R, Eickhorst T, Schulze-Lefert P. 2012. Revealing structure and assembly cues for Arabidopsis root-inhabiting bacterial microbiota. Nature 488: 91-95.

Chen L, Luo S, Chen J, Wan Y, Liu C, Liu Y, Pang X, Lai C, Zeng G. 2012. Diversity of endophytic bacterial populations associated with Cd hyperaccumulator plant Solanum nigrum L. grown in mine tailings. Applied Soil Ecology 62: 24-30. 


\section{ACCEPTED MANUSCRIPT}

Compant S, Clément C, Sessitsch A. 2010. Plant growth-promoting bacteria in the rhizo- and endosphere of plants: their role, colonization, mechanisms involved and prospects for utilization. Soil Biol Biochem 42: 669-678.

Croes S, Weyens N, Janssen J, Vercampt H, Copaert JV, Carleer R, Vangronsveld J. 2013. Bacterial communities associated with Brassica napus L. grown on trace element-contaminated and non-contaminated fields: a genotypic and phenotypic comparison. Microbial biotechnology 6: $371-384$.

Croes S. 2014. The potential role of plant-associated bacteria to improve the efficiency of phytoremediation of metal-contaminated soils using rapeseed. Doctoral Dissertation. Hasselt University, Belgium.

Croes S, Weyens N, Colpaert J, Vangronsveld J. 2015. Characterization of the cultivable bacterial populations associated with field grown Brassica napus L.: an evaluation of sampling and isolation protocols. Environmental Microbiology DOI: 10.1111/1462-2920.12701.

de Campos SB, Youn JW, Farina R, Jaenicke S, Jünemann S, Szczepanowski R, Beneduzi A, Vargas LK, Goesmann A, Wendisch VF, Passaglia LM. 2013. Changes in root bacterial communities associated to two different development stages of canola (Brassica napus L. var oleifera) evaluated through next-generation sequencing technology. Microb Ecol 65:593-601.

Dell'Amico E, Cavalca L, Andreoni V. 2005. Analysis of rhizobacterial communities in perennial Graminaceae from polluted water meadow soil, and screening of metal-resistant, potentially plant growth-promoting bacteria. FEMS Microbiology Ecology 52: 153-162. 


\section{ACCEPTED MANUSCRIPT}

De Temmerman L, Vanongeval L, Boon W, Hoenig M, Geypens M. 2003. Heavy metal content of arable soils in northern Belgium. Water, Air, and Soil Pollution 148: 61-76.

Duan J, Jiang W, Cheng Z, Heikkila JJ, Glick BR. 2013. The Complete Genome Sequence of the Plant Growth-Promoting Bacterium Pseudomonas sp. UW4. PLoS ONE 8(3): e58640.

Ellis RJ, Morgan P, Weightman AJ, Fry JC. 2003. Cultivation-dependent and independent approaches for determining bacterial diversity in heavy-metal-contaminated soil. Applied and Environmental microbiology 69(6): 3223-3230.

Fisher PJ, Petrini O, Scott HML. 1992. The distribution of some fungal and bacterial endophytes in maize. New Phytol 122: 299-305.

Genrich I, Dixon DG, Glick R. 2000. Plant growth-promoting bacteria that decrease heavy metal toxicity in plants. Canadian Journal of Microbiology 46: 237-245.

Germida JJ, Siciliano SD, Renato de Freitas J, Seib AM. 1998. Diversity of root-associated bacteria associated with field-grown canola (Brassica napus L.) and wheat (Triticum aestivum L.). FEMS Microbiol Ecol 26: 43-50.

Glick BR. 2003. Phytoremediation: synergistic use of plants and bacteria to clean up the environment. Biotechnology Advances 21: 383-393.

Glick BR. 2010. Using soil bacteria to facilitate phytoremediation. Biotechnology Advances 28: 367-374.

Gomez-Balderas CDC, Cochet N, Bert V, Tarnaud E, Sarde CO. 2014. 16S rDNA analysis of bacterial communities associated with the hyperaccumulator Arabidopsis halleri grown on a $\mathrm{Zn}$ and Cd polluted soil. European Journal of Soil Biology 60: 16-23. 


\section{ACCEPTED MANUSCRIPT}

Grispen VMJ, Nelissen HJM, Verkleij JAC. 2006. Phytoextraction with Brassica napus L.: a tool for sustainable management of heavy metal contaminated soils. Environ Pollut 144: 77-83.

Groppa MD, Zawoznik MS, Tomaro ML, Benavides MP. 2008. Inhibition of root growth and polyamine metabolism in sunflower (Helianthus anпииs) seedlings under cadmium and copper stress. Biol Trace Elem Res 126: 246-256.

Hallmann J. 2001. Plant interactions with endophytic bacteria. In: Jeger MJ, Spence NJ, eds. Biotic Interactions in Plant-Pathogen Associations. Wallingford, UK: CABI Publishing. p. 87119.

Hanbo Z, Changqun D, Qiyong S, Weimin R, Tao S, Lizhong C. Zhiwei Z, Bin H. 2004. Genetic and physiological diversity of phylogenetically and geographically distinct groups of Arthrobacter isolated from lead-zinc mine tailings. FEMS Microbiology Ecology 49, 333-341.

Hernández-Allica J, Becerril JM, Garbisu C. 2008. Assessment of the phytoextraction potential of high biomass crop plants. Environ. Pollut 152: 32-40.

Izumi H, Anderson IC, Killham K, Moore ERB. 2008. Diversity of predominant endophytic bacteria in European deciduous and coniferous trees. Can J Microbiol 54: 173-179.

Kelly JJ, Häggblom MM, Tate RL. 2003. Effects of heavy metal contamination and remediation on soil microbial communities in the vicinity of a zinc smelter as indicated by analysis of microbial community phospholipid fatty acid profiles. Biol Fertil Soils 38:65-71.

Kid P, Mench M, Álvarez-López V, Bert V, Dimitriou I, Friesl-Hanl W, Herzig R, Janssen J, Kolbas A, Müller I, Neu S, Renella G, Ruttens A, Vangronsveld J, Puschenreiter M. 2015. Agronomic practices for improving gentle remediation of trace element-contaminated soils. International Journal of Phytoremediation DOI: 10.1080/15226514.2014.1003788. 


\section{ACCEPTED MANUSCRIPT}

Kirkham MB. 2006. Cadmium in plants on polluted soils: Effects of soil factors, hyperaccumulation, and amendments. Geoderma 137: 19-32.

Lindow SE, Brandl MT. 2003. Microbiology of the Phyllosphere. Appl Environ Microbiol 69: 1875-1883.

Lodewyckx C, Vangronsveld J, Porteous F, Moore ERB, Thagavi S, van der Lelie D. 2002.

Endophytic bacteria and their potential applications. Crit Rev Plant Sci 21:583-606.

Ma Y, Rajkumar M, Freitas H. 2009. Isolation and characterization of Ni mobilizing PGPB from serpentine soils and their potential in promoting plant growth and Ni accumulation by Brassica spp. Chemosphere 75: 719-725.

Ma Y, Prasad MNV, Rajkumar M, Freitas H. 2011. Plant growth promoting rhizobacteria and endophytes accelerate phytoremediation of metalliferous soils. Biotechnology Advances 29: 248258.

Marchiol L, Sacco P, Assolari S, Zerbi G. 2004. Reclamation of polluted soil: phytoremediation potential of crop-related Brassica species. Water Air Soil Pollut 158: 345-356.

Marques APGC, Pires C, Moreira H, Rangel AOSS, Castro PML. 2010. Assessment of the plant growth promotion abilities of six bacterial isolates using Zea mays as indicator plant. Soil Biology \& Biochemistry 42: 1229-1235.

Mench M, Vangronsveld J, Didier V, Clijsters H. 1994. Evaluation of metal mobility, plant availability and immobiliation by chemical agents in a limed silty soil. Environ Pollut 86: 279286. 


\section{ACCEPTED MANUSCRIPT}

Mergeay M, Nies D, Schlegel HG, Gerits J, Charles P, Van Gijsegem F. 1985. Alcaligenes eutrophus $\mathrm{CH} 34$ is a facultative chemolithotroph with plasmid-bound resistance to heavy metals. J Bacteriol 162: 328-334.

Montalbán B, García-Gonzalo P, Pradas del Real AE, Alonso J, Lobo MC, Pérez-Sanz A. 2014. Brachypodium distachyon tolerance to metals under in vitro conditions: a comparison with two metal-tolerant energy crops. Fresenius environmental bulletin 23(9): 2086-2092.

Nagajyoti PC, Lee KD, Sreekanth TVM. 2010. Heavy metals, occurrence and toxicity for plants: a review. Environ Chem Lett 8: 199-216.

Panagos P, Van Liedekerke M, Yigini Y, Montanarella L. 2013. Contaminated sites in Europe: Review of the current situation based on data collected through a European network. Journal of Environmental and Public Health, Article ID 158764, 11 pages.

Patten CL, Glick BR. 2002. The role of bacterial indoleacetic acid in the development of the host plant root system. Appl Environ Microbiol 68: 3795-801.

Peralta JR, Gardea-Torresdey JL, Tiemann KJ, Gomez E, Arteaga S, Rascon E, Parsons JG. 2001. Uptake and effects of five heavy metals on seed germination and plant growth in alfalfa (Medicago sativa L.). Bull Environ Contam Toxicol 66: 727-734.

Rajkumar M, Ae N, Freitas H. 2009. Endophytic bacteria and their potential to enhance heavy metal phytoextraction. Chemosphere 77: 153-160.

Rajkumar M, Sandhya S, Prasad MNV, Freitas H. 2012. Perspectives of plant-associated microbes in heavy metal phytoremediation. Biotechnology Advances 30: 1562-1574. 


\section{ACCEPTED MANUSCRIPT}

Remans T, Nacry P, Pervent M, Girin T, Tillard P, Lepetit M, Gojon A. 2006. A central role for the nitrate transporter NRT2.1 in the integrated morphological and physiological responses of the root system to nitrogen limitation in Arabidopsis. Plant Physiology 140: 909-921.

Remans T, Thijs S, Truyens S, Weyens N, Schellingen K, Keunen E, Gielen H, Cuypers A, Vangronsveld J. 2012. Understanding the development of roots exposed to contaminants and the potential of plant-associated bacteria for optimization of growth. Annals of Botany 110: 239-252.

Reynoso-Cuevas L, Gallegos-Martínez ME, Cruz-Sosa F, Gutiérrez-Rojas M. 2008. In vitro evaluation of germination and growth of five plant species on medium supplemented with hydrocarbons associated with contaminated soils. Bioresource Technology 99: 6379-6385.

Rouch DA, Lee TOB, Morby AP. 1995. Understanding cellular responses to toxic agents: a model for mechanisms-choice in bacterial resistance. J Ind Microbiol 14: 132-141.

Schellingen K, Van Der Straeten D, Vandenbussche F, Prinsen E, Remans T, Vangronsveld J, Cuypers A. 2014. Cadmium-induced ethylene production and responses in Arabidopsis thaliana rely on ACS2 and ACS6 gene expression. BMC Plant Biology 14 DOI: 10.1186/s12870-0140214-6.

Sessitsch A, Kuffner M, Kidd P, Vangronsveld J, Wenzel WW, Fallmann K, Puschenreiter M. 2013. The role of plant-associated bacteria in the mobilization and phytoextraction of trace elements in contaminated soils. Soil Biology \& Biochemistry 60: 182-194.

Sheng XF, Xia JJ. 2006. Improvement of rape (Brassica napus) plant growth and cadmium uptake by cadmium-resistant bacteria. Chemosphere 64: 1036-1042. 


\section{ACCEPTED MANUSCRIPT}

Soderberg KH, Bååth E. 1998. Bacterial activity along a young barley root measured by the thymidine and leucine incorporation techniques. Soil Biol Biochem 30: 1259-1268.

Truyens S, Weyens N, Cuypers A, Vangronsveld J. 2014. Bacterial seed endophytes: genera, vertical transmission and interaction with plants. Environmental Microbiology Reports. DOI: $10.1111 / 1758-2229.12181$.

Vamerali T, Bandiera M, Mosca G. 2010. Field crops for phytoremediation of metalcontaminated land. A review. Environ Chem Lett 8: 1-17.

Van Ranst E, Verloo M, Demeyer A, Pauwels JM. 1999. Manual for the Soil Chemistry and Fertility Laboratory. Ghent, Belgium: Ghent University, Faculty Agricultural and Applied Biological Sciences.

Vangronsveld J, Herzig R, Weyens N, Boulet J, Adriaensen K, Ruttens A., Thewys, T., Vassilev, A., Meers, E., Nehnevajova, E., van der Lelie, D., Mench, M. 2009. Phytoremediation of contaminated soils and groundwater: lessons from the field. Environ Sci Pollut Res Int 16: 765794.

Velázquez E, Rojas M, Lorite MJ, Rivas R, Zurdo-Piñeiro JL, Heydrich M, Bedmad EJ. 2008. Genetic diversity of endophytic bacteria which could be find in the apoplastic sap of the medullary parenchym of the stem of healthy sugarcane plants. Journal of Basic Microbiology 48: $118-124$.

Vlarebo (Vlaams Reglement Bodemsanering). 2009. Vlaams Reglement Betreffende bodemsanering en bodenbescherming. Openbare Vlaamse Afvalstoffenmaatschappij. D/2005/5024/44. February 2009. 203 pp. 


\section{ACCEPTED MANUSCRIPT}

Weyens N, Taghavi S, Barac T, van der Lelie D, Boulet J, Artois T, Carleer R, Vangronsveld J. 2009a. Bacteria associated with oak and ash on a TCE-contaminated site: characterization of isolates with potential to avoid evapotranspiration of TCE. Environ Sci Pollut Res 16: 830-843.

Weyens N, Van der Lelie D, Taghavi S, Vangronsveld J. 2009b. Phytoremediation: plantendophyte partnerships take the challenge. Current Opinion in Biotechnology 20: 248-254.

Weyens N, Croes S, Dupae J, Newman L, van der Lelie D, Carleer R, Vangronsveld J. 2010. Endophytic bacteria improve phytoremediation of $\mathrm{Ni}$ and TCE co-contamination. Environ Pollut 158: $2422-2427$.

Witters N, Mendelsohn RO, Van Slycken S, Weyens N, Schreurs E, Meers E, Tack F, Carleer R, Vangronsveld J. 2012. Phytoremediation, a sustainable remediation technology? Conclusions from a case study. I: Energy production and carbon dioxide abatement. Biomass and bioenergy 39: 454-469.

Zhang H, Forde B. 1998. An Arabidopsis MADS box gene that controls nutrient-induced changes in root architecture. Science 279: 407-409.

Zhang YZ, He LY, Chen ZJ, Wang QY, Quian M, Sheng XF. 2011. Characterization of ACC deaminase-producing endophytic bacteria isolated from copper-tolerant plants and their potential in promoting the growth and copper accumulation of Brassica napus. Chemosphere 83: 57-62.

Zhang WH, Huang Z, He LY, Sheng XF. 2012. Assessment of bacterial communities and characterization of lead-resistant bacteria in the rhizosphere soils of metal-tolerant Chenopodium ambrosioides grown on lead-zinc mine tailings. Chemosphere 87: 1171-1178. 


\section{ACCEPTED MANUSCRIPT}

Table 1. Total and $\mathrm{Ca}\left(\mathrm{NO}_{3}\right)_{2}$-extractable metal concentrations ( $\mathrm{mg} \mathrm{kg}^{-1}$ dry soil), $\mathrm{pH}$ and organic matter $(\mathrm{OM})$ content of the soil in the experimental field. Results are mean $\pm \mathrm{SE}$ of composite soil samples (depth: 0-25 cm).

\begin{tabular}{|c|c|c|c|c|c|c|}
\hline & $\mathrm{Zn}$ & $\mathrm{Cd}$ & $\mathrm{Cu}$ & $\mathrm{Pb}$ & \multirow{2}{*}{$\begin{array}{l}\text { OM } \\
(\%)\end{array}$} & \multirow[t]{2}{*}{$\mathrm{pH}-\mathrm{KCl}$} \\
\hline & \multicolumn{4}{|c|}{$\left(\mathrm{mg} \cdot \mathrm{kg}^{-1}\right)$} & & \\
\hline Total concentration & $\begin{array}{c}343 \pm \\
16\end{array}$ & $\begin{array}{c}0.36 \pm \\
0.04\end{array}$ & $35 \pm 2$ & $185 \pm 10$ & 1.9 & $\begin{array}{c}5.6 \pm \\
0.1\end{array}$ \\
\hline $\begin{array}{l}\mathrm{Ca}\left(\mathrm{NO}_{3}\right)_{2^{-}} \\
\text {extractable }\end{array}$ & $81 \pm 20$ & $\begin{array}{c}0.15 \pm \\
0.02\end{array}$ & $0.18 \pm 0.01$ & $\begin{array}{c}0.38 \pm \\
0.02\end{array}$ & & \\
\hline $\begin{array}{c}\text { Background } \\
\text { values }^{\mathrm{a}}\end{array}$ & $25-70$ & $0.1-0.5$ & $3-15$ & $5-40$ & 2.3 & \\
\hline $\begin{array}{c}\text { Remediation } \\
\text { values }^{\mathrm{b}}\end{array}$ & 333 & 2 & 120 & 200 & 2 & \\
\hline
\end{tabular}

\footnotetext{
ac Common range' values in sandy soils in Flanders according to De Temmerman et al. (2003).

${ }^{\mathrm{b}}$ Clean up values for remediation of a 'standard' agricultural soil (2\% organic matter and $2 \%$ clay) according to the Flemish legislation on soil remediation (Vlarebo, 2009).
} 


\section{ACCEPTED MANUSCRIPT}

Table 2. Total numbers of colony-forming units (cfu) per gram fresh weight of soil, rhizosphere and B. napus tissues isolated from $\mathrm{Zn}$ contaminated site.

\begin{tabular}{|c|c|}
\hline Compartment & $\mathrm{cfu} \mathrm{g}^{-1}$ fresh weight \\
\hline Soil & $62 \times 10^{4} \pm 52.8 \times 10^{4}(8) \mathrm{b}$ \\
\hline Rhizosphere & $30 \times 10^{6} \pm 15.3 \times 10^{6}(20) \mathrm{a}$ \\
\hline Root & $13 \times 10^{4} \pm 10.1 \times 10^{4}(17) \mathrm{b}$ \\
\hline Stem & $61 \times 10 \pm 57.0 \times 10(3) \mathrm{c}$ \\
\hline
\end{tabular}

Mean values \pm SE, $n=3$ independent replicates. The numbers of different bacterial genus are marked in parentheses. Letters represent significant differences between compartments after ANOVA and Tukey's test $(\mathrm{p} \leq 0.05)$ 


\section{ACCEPTED MANUSCRIPT}

Table 3. Phenotypic characterization of all purified bulk soil, rhizosphere, root and stem isolated bacteria.

\begin{tabular}{|l|c|c|c|c|}
\hline & Soil & Rhizosphere & Root & Stem \\
\hline SID & 1.86 & 3.89 & 23.76 & 0.00 \\
\hline OA & 36.68 & 5.53 & 20.79 & 53.79 \\
\hline ACC & 68.39 & 18.94 & 69.25 & 0.26 \\
\hline IAA & 35.38 & 6.49 & 47.21 & 26.76 \\
\hline Acetoin & 5.57 & 10.32 & 7.07 & 20.00 \\
\hline P sol & 4.09 & 1.63 & 17.39 & 0.00 \\
\hline $\mathrm{N}_{2}$ fix & 1.05 & 1.05 & 1.20 & 53.33 \\
\hline Zn $\quad(1$ & 23.28 & 25.40 & 6.18 & 40.00 \\
\hline Cd $(0.8$ & 22.27 & 25.07 & 21.68 & 0.00 \\
\hline
\end{tabular}

Data are relative abundances expressed in percentages of the total number of cultivable bacteria isolated per gram fresh weight bulk soil, rhizosphere, roots and stem. Bacterial strains were tested for metal resistance $(\mathrm{Cd}$ or $\mathrm{Zn})$ and potential plant growth-promoting characteristics: Phosphorus solubilization ( $\mathrm{P}$ sol), nitrogen fixation $\left(\mathrm{N}_{2}\right.$ fix), production of siderophores (SID), organic acids (OA), ACC deaminase (ACC), indole-3-acetic acid (IAA) and acetoin (Acetoin). 


\section{ACCEPTED MANUSCRIPT}

Table 4. Metal tolerance and PGP characteristics of selected bacteria for inoculation in B. napus seeds.

\begin{tabular}{|c|c|c|c|c|c|c|c|c|c|c|c|c|}
\hline Com & Str & Identificat & $\mathrm{Zn}$ & $\mathrm{Cd}$ & $\mathrm{Fe} 0 \mu$ & $\mathrm{Fe} 0.25$ & $\mathrm{O}$ & $\mathrm{A}$ & $\mathrm{IA}$ & $\mathrm{Ac}$ & $\mathrm{Ps}$ & $\mathrm{N}$ \\
\hline Rh & 25 & Staphyloc & ++ & +++ & - & - & ++ & - & - & + & - & - \\
\hline Soil & 222 & Arthrobac & ++ & +++ & - & - & ++ & ++ & - & - & - & + \\
\hline Root & 228 & Pseudom & ++ & ++ & + & + & + & ++ & + & - & ++ & - \\
\hline Root & 246 & Serratia & ++ & +++ & + & + & ++ & ++ & ++ & - & - & - \\
\hline Root & 256 & Pseudom & ++ & + & + & + & - & + & ++ & + & ++ & + \\
\hline Root & 262 & Pseudom & + & + & ++ & - & + & ++ & ++ & + & - & - \\
\hline
\end{tabular}

Compartment (Comp.), Rhizosphere (Rh), Organic acids (OA), ACC (ACC deaminase activity),

IAA (indole-3-acetic acid), Ace (Acetoin), phosphate solubilization (Psol), nitrogen fixation ( $\mathrm{N}$ fix). + low, +++ high production. 


\section{ACCEPTED MANUSCRIPT}
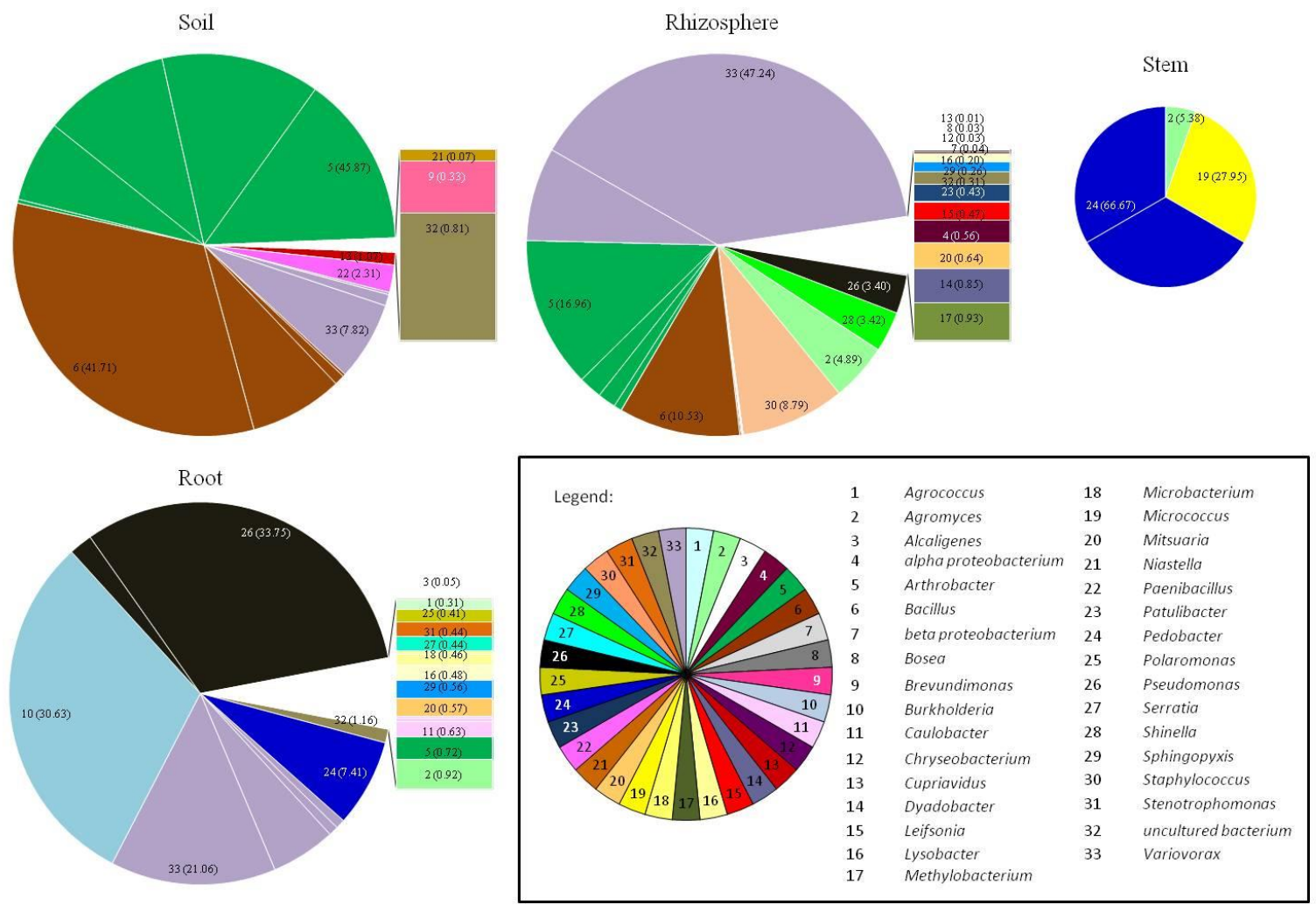

Fig.1. Diversity and abundance of cultivable bacteria isolated from bulk soil, rhizosphere, root and stem of B. napus plants grown in a $\mathrm{Zn}$ contaminated site. Abundance percentages are shown in parentheses. Bacterial strains with abundances lower than $1 \%$ are shown next to the pie diagram. 


\section{ACCEPTED MANUSCRIPT}

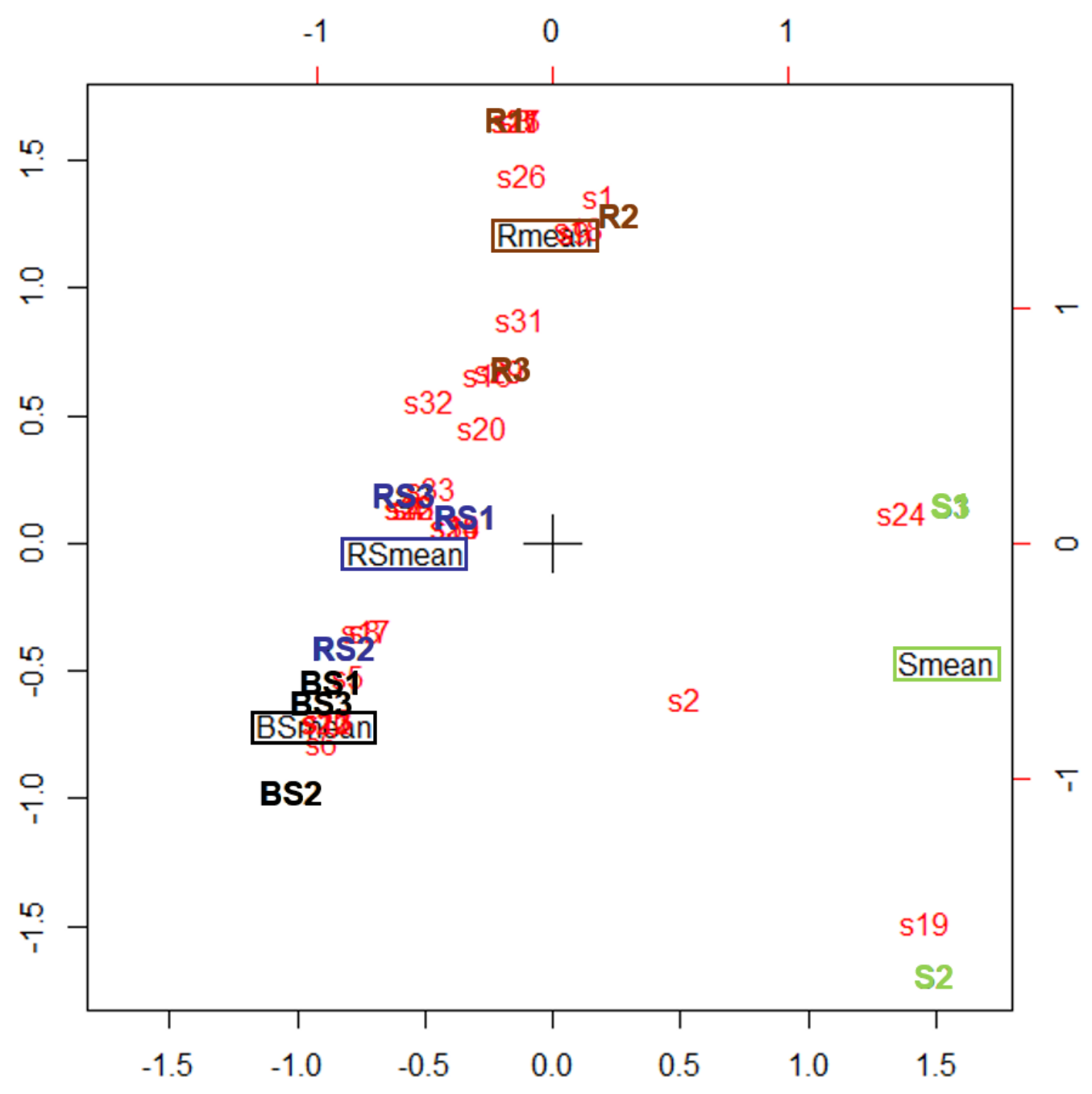

Fig.2. Correspondence analysis of bacterial communities isolated from soil, rhizosphere and $B$. napus samples. s1-s33 represent a bacterial genus (see legend in Figure 1). BS (Bulk soil), RS (Rhizosphere soil), R (Root), S (Stem). Three repetitions of each compartment were used to make the mixed sample (mean). 


\section{ACCEPTED MANUSCRIPT}

(a)

$\square \mathrm{Zn}(300 \mu \mathrm{M}) \quad \square \mathrm{Zn}(1000 \mu \mathrm{M})$

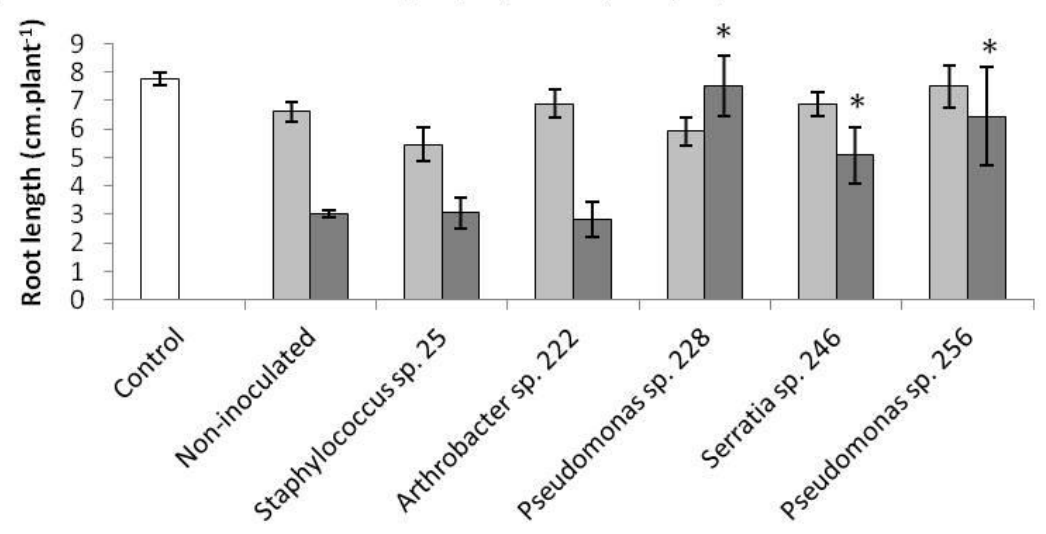

(b)

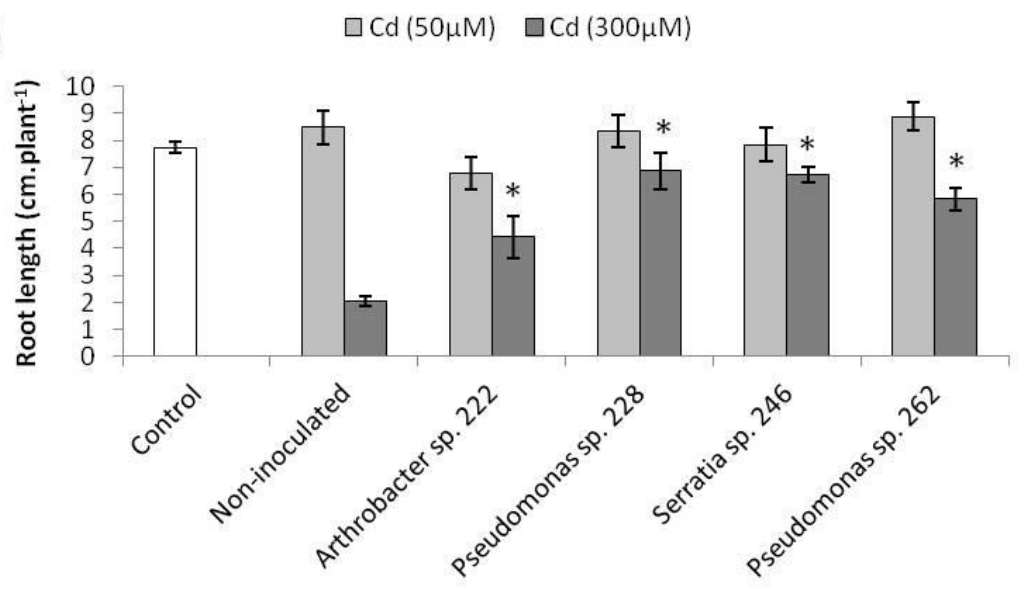

Fig.3. Root length of 5-days B. napus seedlings after inoculation of PGP bacterial strains in presence of (a) $\mathrm{Zn}$ and (b) Cd. Asterisks (*) represent significant differences between noninoculated and inoculated plants after one-way ANOVA and Tukey's test $(\mathrm{p} \leq 0.05$; mean values $\pm \mathrm{SE} ; \mathrm{n}=4)$. 